\title{
LEADERSHIP STYLE AND ITS INFLUENCE ON TEACHER PERFORMANCE IN SMAN 1 GAMBIRAN BANYUWANGI
}

\author{
Nur Ahmadi ${ }^{1}$ ) \\ Suwignyo Widagdo²) \\ Yuniorita Indah $\mathrm{H}^{3}$ )
}

\section{Higher Education of Economic Mandala \\ Email :stie-mj@stie-mandala.ac.id}

\begin{abstract}
The objective of this researchwas to analyze the influence of Leadership Style, Work Atmosphere, and Career Development on Teacher Performance.The object of this research is teacher at SMAN I GambiranBanyuwangi. Type of this research was quantitative causality. Respondents who were samples in this research were 51 teachers consisting of 44 civil servant teachers and 7 non-civil servant teachers. Data analysis tool used in this research was doubled linear regression. Technically, SPSS software version 2.2 was used to analyze the data. Respondents were 51 teachers consisting of civil servant and non-civil servant teachers. The results showed that the leadership style, work atmosphere and teacher career development partially affect the improvement of teacher performance. From the analysis result, three variables simultaneously also affect the performance of teachers. While of the three independent variables studied, the dominant variablewhich affects teacher performance was the principal leadership style. The results of this researchreinforced previous studies which state that leadership style is a very important variable in improving performance. The implications of this research showed that to improve teacherperformance, the principal needed to have a leadership style which is appropriate to the character of the organization he leaded. A supportive working environment would help teachers feel comfortable and secure so that their performance improves. Similarly career development needed to be planned so that teachers had the motivation to improve performance in the long termand it would be the capital to fulfill the expectations in their career development. The advice was given to improve career development performance in SMAN 1 GAMBIRAN is by develop the principal leadership style by the improvement of task oriented stye to support the implementation of the curiculum instead.
\end{abstract}

Keywords: Leadership Style, Work Atmosphere, Career Development, and Teacher Performance.

\section{INTRODUCTION}

Education and teaching learning process can be well established depending on the performance and teachers productivity in teaching. One of the indicators of performance improvement is the increasing of work discipline. Work discipline of the employee is a reflection of the attitudes and personal teachers which is seen to obey all the rules in the school. Teacher performance is influenced by several things such as principal leadership style and work atmosphere. The principal as the supreme leader who is very influential to determines the progress of the school must have the ability of administration, have a high commitment, and have flexibility in carrying out his duties. Good principal leadership should be able to improve the performance of teachers through training of the ability of educational staff program. Therefore the principal must have the personalities or traits and abilities and skills to lead an 
educational institution. The leadership is come from the word 'leader'. A leader is a person who able to lead or arrange. The conclution from the concept is the ability to influent the member of group to reach the organisation purpose

At this time, leadership-oriented task tends to be interested and liked by subordinates. By using this style, the principal tries to give more motivation rather than oversee them. Principal leadership is one of the factors that give contribution to the teacher performance.Leadership in accordance with the conditions and the environment may bring up teachers' passion in improving their performance.They encourage group members to carry out tasks by allowing subordinates to participate in decision-making, create an atmosphere of friendship and relationship of mutual trust and respect with members of the group (Gitosudarmo, 2002: 17)

The leadership stye is the behavior from a person that able to motivate, influence, arrange, and comunicate to the member. A leader has a duty to do the leadership. At this time a leader is a person but the leadership is the activity to lead. In this case use the effort to combine the leader and the member to reach the balance the situation is important. Mulyasa (2003 : 108) said the leadership style is the way to influence the member. The are many the leadership style but people hard to choose the best.

Luthan (2006 : 638) said the leadership is the "black box" mean that unexplaination concept, has the power to influence the human but the function is hard to explain. People try to make the concept but most of depend to oriented teory

Success in achieving these goals, principal has an important role in coordinating, mobilizing and aligning the available educational resources. The leadership of the principal is one of the factors that can drive the school to realize its vision, mission, goals and objectives through School programs implemented in a planned and gradual.

According to Syaril (2013: 1) in his thesis submitted that the results which were obtained from observations and data analysis and hypothesis testing were: the influence among leadership style variables (X1) teacher attitudes (X2), teacher discipline (X3) on teacher performance (Y) partially (each) has a positive and significant influence, as well as simultaneously there was influence among leadership style, teacher attitudes and teacher discipline on teacher performance.

The conclusion of this research was the more democratic style of leadership applied by principal would give better impact to teacher performance. The better teacher attitudes and teacher discipline would also have better impact on teacher performance.

In this global competition, educational institutions or schools are required to emerge with effective and productive institutional performance. Principals in charge of education and learning in schools should be able to convince the community that everything is going well, including plan and curriculum implementation, provision and utilization of teacher resources, recruitment of student resources, school and parents collaboration, and prospective alumnae alumni.

Poerwanto (2008: 71 ) said that environment as the direcly influence the organization inside it such as the employee, leadership comite, and manage comite. Intern environment is the controled environment, as the extern the environment is undirect influence that hard to controled. The extern environment such as competitor, supplyer, science, labor organization, tecnology, goverment policy, and social organization

Extern environment factors has a big influence toorganization to reach the purpose. Economic factor, politic, law, culture, demograph,competitor, environment, tecnology are the urgent factors to influent the organization. The 
intern factors can be in the right condition but the extern factors can caused the problems (Sopiah, $2008: 6$ )

Generally, the education system in Banyuwangi and specifically in SMAN 1 GAMBIRAN have to carry out its duties and functions in order to realize the national objectives as stated in RI Law no. 20 of 2003 on National Education System. National Education functions to develop the ability and to build the character and civilization of a dignified nation in order to educate the nation's life, aims to develop the potential of learners to become human beings who believe and piety to God Almighty, noble, healthy, independent and become citizens which is democratic and responsible. So, SMAN 1 GAMBIRAN provides curriculum oriented to the development of students both academic and non academic.

Profesional ability a principel as a leader is responsibility to make the conduse environment to study and to teach to help the teachers work in comfort situation, also make the good relation among the teachers or the teachers to the leader. In this time the principal as the role model to build the spirit and motivate the teachers to work much better. The purpose from the writer to analize the partial matter as the style of the principal leadership, work environment, and progress the career of teachers in SMAN 1 Gambirab. The limited problem use to deeply research, focus and keep stay in the main problem. The writer focus to purpuse to the principal leadership in SMAN 1 Gambiran period 2016 /2017

\section{RESEARCH METHODS}

The type of this research was causality research. The location of this research was at SMAN 1 GAMBIRAN with a population of 51 people (41 civil servants, 10 non-civil servants teacher). Taking note of the above statement, because the population was less than 100so, the entire population became the sample.Twovariables analyzed in this research. They were; a). Independent Variable: This variable is commonly called as stimulus, predictor, and antecedent variable. In Indonesian is often referred to as variabelbebas. The independent variable is the variable that influences or causes the change or leads to dependent or bound variable (Sugiyono, 2013). The independent variables in this research were leadership (X1), work atmosphere (X2), and career development (X3), b) Dependent variable: This variableiscommonly called asoutput, criteria, and consequent variable. In Indonesian it is often referred to as variabelterikat. The dependent variable is the variable that is influenced or becoming a result, because of the independent variables (Sugiyono, 2013). Dependent variable in this research was teacher performance $(\mathrm{Y})$.

The data sources used in this research were: a). Primary data is a research data obtained directly from original source (not from intermediary source) and data collected specifically to answer research questions in accordance with the wishes of researchers, b) Secondary data is the source of research data obtained by researchers indirectly.

\section{RESULTS ANALYSIS}

\section{Multiple Regression Analysis}

Multiple regression analysis is an analysis tool for forecasting the influence of two independent variables or more on the dependent variable to prove the existence of functional relation or causality relationship between two independent variables (X1), (X2) and (X3) with one dependent variable ( $Y$ ).

Based on statistical processing with IBM SPSS Statistics Version 23 program obtained the following results: 
Table The Result of Influence of independent Variable todependent Variables Coefficients $^{a}$

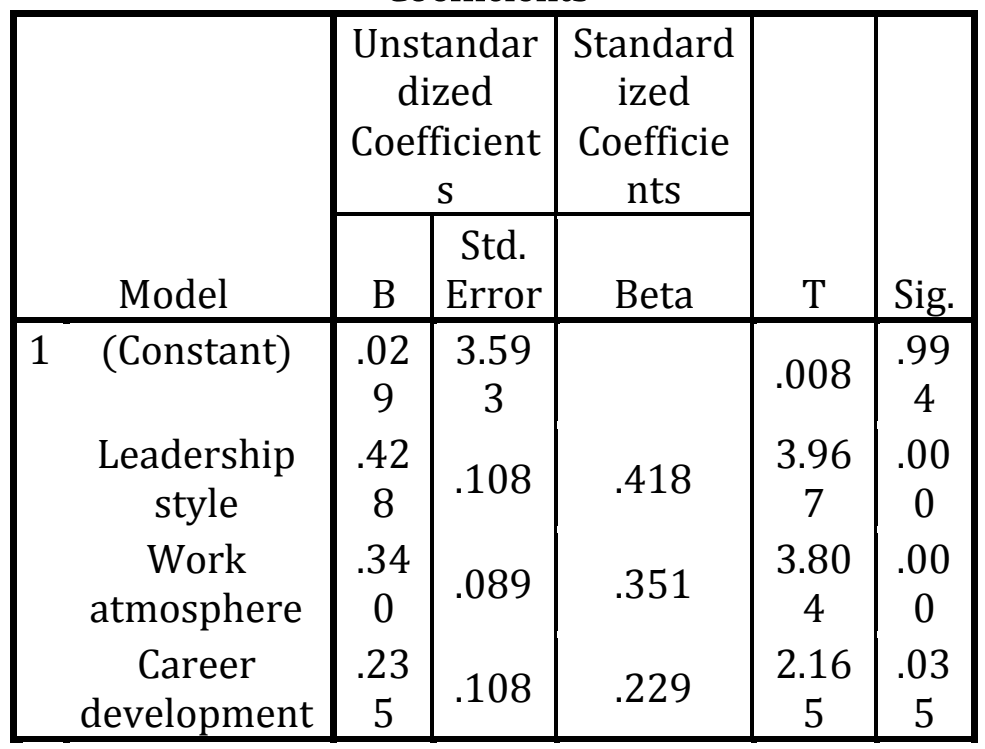

a. Dependent Variable: teacher performance

Based on the table above, it is known that the results of multiple regression equations $\hat{Y}=0.029+0.428 X 1$ $+0.340 \times 2$. $+0.235 \times 3$. The result of double regression equation calculation was known that the contribution of influence of leadership style variable was greater than contribution of influence of work atmosphere and career development to teacher performance.

\section{Hypothesis Testing}

\subsection{Test $\mathrm{T}$}

\subsubsection{Effect of Leadership Style on Teacher Performance}

Based on table the result of the influence of independent variables on dependent variable (coefficientsds)was known that the value of thitungobtained in the data analysis of the influence of leadership style on teacher performance was 3.967. Therefore $t_{\text {hitung }}>t_{\text {table }}$ (3.967> 2.021), then $\mathrm{H}_{0}$ was rejected and $\mathrm{H}_{1}$ was accepted. Thus, the hypothesis which stated "There was influence of leadership style on teacher performance", was significant acceptable.

\subsubsection{Effect of Working Atmosphere on Teacher Performance}

Based on table the result of independent variables to dependent variables (coefficientsds) it was known that the value of $t_{\text {count }}$ obtained in data analysis of the influence of work atmosphere on teacher performance was 3.804. Therefore $t_{\text {count }}>$ ttable (3.804 $>$ 2.021), then $\mathrm{H} 0$ was rejected and $\mathrm{H} 1$ was accepted. Thus, the hypothesis which stated "There was an influence of working atmosphere on teacher performance", was significant acceptable.

2.1.3 Effect of Career Development on Teacher Performance 
Based on the presentation of the result table of independent variables to the dependent variable (coefficientsds), it was known that the $t_{\text {count }}$ value obtained in the data analysis of the influence of career development on teacher performance was 2,165 . Therefore $t_{\text {count }}>$ t table (2.165> 2.021 ), then $\mathrm{H} 0$ was rejected and $\mathrm{H} 1$ was accepted. Thus, the hypothesis which stated "There was an influence of career development on teacher performance", was significant acceptable.

\subsubsection{Influence of Leadership Style, Work}

Atmosphere and Career Development

Together to Teacher Performance

Based on $\mathrm{F}$ or Anova test results obtained $\mathrm{F}$ count was 78.327 and $\mathrm{F}$ table was 2.80 .
Since Fcount $>$ Ftable $(78,327>2,80)$, H0 was rejected and $\mathrm{H} 1$ was accepted. Thus, the hypothesis which stated "There was influence of leadership style, work atmosphere and career development together on teacher performance", was significant acceptable.

\subsection{Test $F$}

The modelsuitabilitytestwas comparing the value of Fhitung with $F_{\text {tabel. }}$ The value of Fitungthat is obtained in the data analysis of the influence of leadership style, work atmosphere and career development together on teacher performance was known from the following table.

Table Test F (Anova)

ANOVA $^{\mathrm{a}}$

\begin{tabular}{|c|l|l|l|l|l|}
\hline Model & $\begin{array}{l}\text { Sum } \\
\text { of } \\
\text { Squar } \\
\text { es }\end{array}$ & Df & $\begin{array}{l}\text { Mean } \\
\text { Squar }\end{array}$ & & \\
\hline 1 Regres & 4096. & 3 & 1365. & 78. & Sig. \\
sion & 542 & 514 & 327 & $.000^{\mathrm{b}}$ \\
Residu & 819.3 & 47 & 17.43 & & \\
al & 80 & 4 & & \\
Total & $\begin{array}{c}4915 . \\
922\end{array}$ & 50 & & & \\
& & & & \\
\hline
\end{tabular}

a. Dependent Variable: teacher performance

b. Predictors: (Constant), Career Development, Work Atmosphere, Leadership Style

Source: Results of SPSS Data Processing

Since Fcount $>$ Ftable (78.327 $>$ 2.80), therefore, the regression model $\hat{Y}=0.029$

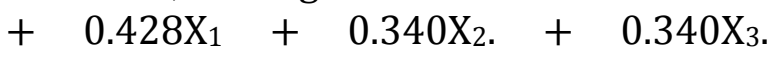
Significant and could be used to predict teacher performance.

\subsection{Coefficient of Determination (R2)}

Based on statistical processing with IBM SPSS Statistics Version 23 program obtained the following results:

Table Multiple Correlation Coefficient Measurement Results and Double Variable Determination Coefficient Variable to Tied Variables

\section{Model Summaryb}

\begin{tabular}{|l|l|l|l|l|}
\hline $\begin{array}{l}\text { Mod } \\
\text { el }\end{array}$ & $\mathrm{R}$ & $\begin{array}{l}\text { R } \\
\text { Squa } \\
\text { re }\end{array}$ & $\begin{array}{l}\text { Adjuste } \\
\text { d R R Rare }\end{array}$ & $\begin{array}{l}\text { Std. Error } \\
\text { of the } \\
\text { Sstimate }\end{array}$ \\
\hline 1 & $.913^{\mathrm{a}}$ & .833 & .823 & 4.175 \\
\hline
\end{tabular}

Development, Work Atmosphere, Leadership Style

b. Dependent Variable: teacher performance

Source: Results of SPSS Data Processing

Based on the result of statistical calculation Coefficient of Determination (r2) or R square was known that the coefficient of determination among the variables of leadership style, work 
atmosphere and career development together with teacher performance variable was 0.833 . That was, $83.3 \%$ of the diversity or variance of teacher performance could be explained jointly from the variables of leadership style, work atmosphere and career development, and or the amount of contribution of leadership style variable, work atmosphere and career development together towards teacher performance variable equal to $83.3 \%$. The remaining $16.7 \%$ was the contribution of other factors to teacher performance variables but not examined.

\section{INTERPRETATION}

\section{Effect of Principal Leadership Style on Teacher Performance at SMAN I GambiranBanyuwangi}

The result of regression equation showed the influence of Principal Leadership Style on Teacher Performance in SMAN I GambiranBanyuwangi, the value was 0,428 or equal to $42.8 \%$. Because of the positive influence, so, if the Principal Leadership Style (X1) increased, then the increase would be offset by improvements in Teacher Performance at SMAN I GambiranBanyuwangi.

This result showed that Teacher Performance at SMAN I GambiranBanyuwangi was partially influenced by Principal Leadership Style $42,8 \%$ from indicator of task oriented style and people oriented style.

It was in line with the Leadership Style theory of Soekarso et al. (2010: 45), explained Principal leadership style is the principal's style to influence teachers and staff on task-oriented tasks and taskoriented and people-oriented tasks.

The task-oriented style of the principal's style of leadership showed the principal's style of focusing on education at the school at SMAN I GambiranBanyuwangi showed the leader's efforts to plan and manage the implementation of teaching and learning at school to be a role model for all school members, especially teachers in carrying out teaching and learning activities. This understanding was in line with Mulyasa(2007: 98) which showed that the principal can play a leader, innovator, and motivator in his school. These findings suggested that the task oriented style in the leadership style of the principal of SMAN I Gambiran could affect teacher performance.

Guidance and academic services from principal for teachers and employees on a regular basis were held every Monday at SMAN 1 GAMBIRAN proved affective in providing direction to perform tasks and responsibilities professionally according to the main task and function of teachers. The example given by the principal would be a benchmark for the performance of teachers and employees in developing schools, especially in the improvement of academic and non academic achievement. Various jurisprudences were achieved by SMAN 1 GAMBARAN every year from the school, sub-district, district, province and national level as evidence that the principal became a symbol of the success of the organization system in the school.

The findings of the research indicated that there was a positive and significant influence of the principals leadership style on teacher performance in SMAN I GambiranBanyuwangi in line and supported by Marwan (2007), Wahyuni (2008), Suratman (2008), Syahril (2013) Principal leadership partially effected on Teacher Performancesignificantly.

\section{Effect of Working Atmosphere on Teacher Performance at SMAN I GambiranBanyuwangi}

Testing the hypothesis of the influence of work atmosphere on the performance of teachers obtained $t_{\text {countwas }}$ 3.804. Therefore $t_{\text {count }}>t_{\text {table }}(3.804>$ 2.021 ), then $\mathrm{H} 0$ was rejected and $\mathrm{H} 2$ was accepted. Thus, H2 hypothesis stated "There was positive influence and significant work atmosphere on teacher performance in SMAN I GambiranBanyuwangi". 
The result of regression equation showed that the influence of work atmosphere on teacher performance in SMAN I GambiranBanyuwangi showed the value of 0.340 or $34 \%$. Since the effect was positive, if the working atmosphere (X2) increased, then the increase would be offset by improvements in Teacher Performance at SMAN I GambiranBanyuwangi.

This result meant that the Teacher Performance at SMAN I GambiranBanyuwangi was partially influenced by the work atmosphere of $34 \%$ of the indicators of Hygiene, Light or Lighting, Sound, Spatial, Air, and Color, Government Policy and Community Support.

It was in line with the work atmosphere theory of Sopiah (2008: 6), explainedthatwork atmosphere is the condition of employees in the work environment that is felt directly or indirectly affect the work activities of employees due to the influence of Hygiene, Light or Lighting, Sound, Spatial, Air , And Colors, Government policies, and Community Support.

The findings of the research indicated that there was a positive and significant effect of work atmosphere on teacher performance in SMAN I GambiranBanyuwangi in line and supported by Wijaya (2007), Nurita (2012), showed that career development partially influenced performance.

\section{Effect of Career Development on Teacher Performance at SMAN I GambiranBanyuwangi}

Testing the hypothesis of the influence of career development on the performance of teachers obtained $t_{\text {count }}$ of 2.165. Therefore $t_{\text {count }}>t_{\text {table }}$ (2.165> $2.021)$, then $\mathrm{H} 0$ was rejected and $\mathrm{H} 3$ was accepted. Thus, hypothesis H3 stated there was a positive influence and significant career development on teacher performance in SMAN I GambiranBanyuwangi.
The result of regression equation showed that the influence of career development on teacher performance in SMAN I GambiranBanyuwangi showed the value of 0,235 or equal to $23,5 \%$. Because the effect was positive, if the career development (X3) increased, then the increase would be offset by an increase on Teacher Performance at SMAN I GambiranBanyuwangi.

This result meant that Teacher Performance at SMAN I GambiranBanyuwangi was partially influenced by career development of $23.5 \%$ of indicators through promotion, through employee movement or mutation, and recommendation or support from superiors. The findings of the research indicated that there was a positive and significant effect of career development on teacher performance in SMAN I GambiranBanyuwangi in line and supported by Wijaya (2007), Nurita (2012), showed that career development partially influenced performance.

It was in line with Career Development theory of Moenir (1993: 10), explained teacher career development is Teacher Setup to follow professional coaching programs that are prepared towards higher positions in education through promotion, through employee movement or mutation, and Recommendation or support from superiors.

\section{Effect of Principal Leadership Style Variables, Working Atmosphere and Career Development Simultaneously on Teacher Performance at SMAN I GambiranBanyuwangi}

The result of measurement and testing of influence of Headmaster Leadership Style, Work Atmosphere and Career Development Together to Teacher Performance at SMAN I GambiranBanyuwangi, obtained the result that there was a relationship among Leadership Style Headmaster, Work Atmosphere and Career Development Together had an effect on Teacher 
Performance at SMAN I GambiranBanyuwangi equal to 0,913 with strong statement. While the influence of Headmaster Leadership Style, Working Atmosphere and Career Development Together to Teacher Performance in SMAN I GambiranBanyuwangiwas $83.3 \%$ and the rest was $16.7 \%$, it was other factors to the variable, but not examined.

The result of multiple regression test of $\mathrm{F}$ test result equaled to 78,327 . Since $F_{\text {count }}>F_{\text {table }}(78,327>2,80)$, H0 was rejected and $\mathrm{H} 1$ was accepted. Thus, hypothesis $\mathrm{H} 4$ stated there was a positive and significant influence Principal Leadership Style, Work Atmosphere and Career Development together to the performance of teachers at SMAN I GambiranBanyuwangi.

The findings of the research indicated that there was a positive and an significant influence of Principal Leadership Style, Working Atmosphere and Career Development together in line with the result of Haryono (2009) research, concluding that leadership style and work atmosphere have greater influence on performance.

\section{The most dominant variables affect the performance of teachers SMAN 1 Gambiran, Banyuwangi}

Based on the result of multiple regression equation showed that the principal leadership style was the most dominant variable, so to improve the performance of teachers was required to improve the principal style leadership efforts to provide directive and guidance to teachers on the implementation of teaching and learning in SMAN I GambiranBanyuwangi. The result of second influence indicated that work atmosphere at SMAN I GambiranBanyuwangi became the factor that couldcause increase or decrease of teacher performance, and the third career development in SMAN I GambiranBanyuwangi there was fulfillment of teacher desire to get mutation, promotion and education opportunity.

\section{CONCLUSIONS}

Principal leadership style, work atmosphere, and career development simultaneously affected the performance of teachers at SMAN I GambiranBanyuwangi. The most dominant influence on teacher performance in SMAN I GambiranBanyuwangi was Principal Leadership Style

\section{IMPLICATIONS}

The implications of this study indicated that to improve teachers'performance, the principal needed to have a leadership style appropriate to the character of the organization he leaded. A supportive working environment would help teachers comfortable and secure so that their performance improved. Similarly, career development needed to be planned so that teachers had the motivation to improve performance in the long term that would be the capital to meet the expectations in the development of his career.

\section{REFERENCES}

Alisjahbana. 2012.

ManajemenKinerjaPemerintah

Daerah. Yogyakarta:

LaksbangPressindo

BambangSetiaji,

2004.PanduanRisetdenganPende katanKuantitatif, Program PascaSarjanaUniversitasMuhamm adiyah, Surakarta.

E. Mulyasa. 2013. ManajemandanKepemimpinanKepa laSekolah. Jakarta: BumiAksara

Ghozali, Imam. 2016.

AplikasiAnalisisMultivariatdengan

Program IBM SPSS.23 Edisi 8.Semarang:

BadanPenerbitUniversitasDiponeg oro

Gitosudarmo,Indriyo.2002, ManajemenOperasi,edisikedua,Yo gyakarta: BPFE UGM 
Ilyas, Yaslis 1999. KinerjaTeori, PenilaiandanPenelitian, PusatKajianEkonomiKesehatanFa kultasKesehatanMasyarakat. Jakarta: Universitas Indonesia.

Kemendikbud. 2012.

PedomanPelaksanaanPenilaianKi nerja Guru. Jakarta: BPSDMP

Kuncoro, Mudrajad. 2007. MetodeKuantitatif:

TeoridanAplikasiuntukBisnisdan EkonomiEdisi I. Yogyakarta: AMP YKPN.

Mahmudi. $2005 . \quad$ Manajemen, KinerjasektorPublik. Yogyakarta: UPP AMP YKPN

Mangkunegara, Anwar Prabu. 2005. PrilakudanBudayaOrganisasi. Bandung: RenikaAditama

Moh.Nasir. 2011. MetodePenelitian. Bogor: Ghalia Indonesia

Mulyasa,

2003.ManajemenBerbasisSekola

hKonsepStrategidanImplikasi,

Bandung, PT RemajaRosdaKarya.

Nugroho, Rahmad. 2006. Analisisfaktorfaktor yang mempengaruhiKinerjaKaryawan, StudiEmpirispada PT. BTN (Persero) Cabang Bandung. Tesis. Magister ManajemenPascasarjana.

UniversitasDiponegoro

PeraturanPemerintah No 19 tahun 2005 pasal 28 StandarNasionalPendidikan. Jakarta: Depdiknas

Poerwanto, 2008, Budaya Perusahaan, Yogyakarta: PustakaPelajar. Sopiah, 2008, PerilakuOrganisasional, Yogyakarta: CV Andi Offset.

Riduwan 2006, MetodedanTeknikMenyusunTesis, Bandung: Alfabeta

Rivai, $\quad 2009$. MenejemenSumberDayaManusiaun tuk Perusahaan. Jakarta: PT. Raja Grafindo Perkasa.

Rivai, dkk. 2011. KepemimpinandanPerilakuOrganis asi. Jakarta: PT. Raja Grafindo Perkasa.
Robbins, Stephen dan Timothy A. Judge. 2008.

PrilakuOrganisasi.Edisikeduabelas. Jakarta: SalembaEmpat

Soekarso, dkk. 2010. Teori Kepemimpinan. Jakarta: Mitra Wacana Media.

Sopiah. 2008. PerilakuOrganisasional. Yogyakarta:CVAndi Offset

Sudarmanto, R. Gunawan. 2005. AnalisisRegresi Linier Gandadengan SPSS. Yogyakarta: GrahaIlmu

Sugiyono, 2014.StatistikauntukPenelitian. Bandung: CV Alfabeta

2013.MetodePenelitianPendidikan.

Bandung: CV Alfabeta

SuharsimiArikunto.

2006.

ProsedurPenelitianSuatuPende katanPraktik. Jakarta: RinekaCipta.

Suprihatiningrum, Jamil. 2013. Guru Profesional: PedomanKinerja, Kualifikasi\&Kompetensi Guru. Yogyakarta: Ar-Ruzz Media.

Suratman. 2008. Pengaruhkepemimpinan, motivasikerja, dansuasanakerjaterhadapkinerja guru SD di KecamatanKarangmalangSragen. Tesis Program PascasarjanaUniversitasMuhamm adiyah Surakarta

Syahril, Bambang. 2013. PengaruhGayaKepemimpinanKepal aSekolah,

SikapGuruDanDisiplinGuruTerhada pKinerjaGuruSmaNegeriDiKotaMan naBengkuluSelatan. Tesis. Program PascaSarjanaUniversitas Bengkulu.

SyaifulSagala. 2008. AdministrasiPendidikanKontempo rer. Bandung: CV Alfabeta

Undangundang RI no 14 tahun 2005 tentang Guru danDosen. Surabaya: KesindoUtama

Wahyudi. 2009. KepemimpinanKepalaSekolahdala mOrganisasiPembelajaran(Learnin $g$ Organization). Bandung: CV Alfabeta 
Wahyudi.

2012.

Wijaya,I.B.W.,2007.PengaruhKompensasi,

PengembanganPendidikan. Jakarta: PT PrestasiPustakaraya

Wahjosumidjo. 1999.

KepemimpinanKepalaSekolah. Jakarta: PT Raja GrafindoPersada

Wibowo. 2012. ManajemenKinerja. Jakarta: RajawaliPers

Widagdo, Suwignyo. 2015. Konsepsi, TeoridanImplementasiManajemenS umberDayamanusia. Jember: STIE PengembanganKarir,Kepemimpina ndanLingkunganKerjaterhadapKine rjaPegawaiNegeriSipildiRumahSaki tUmumPusatSanglah.Te sis. Univer sitasUdayana.

Wirawan. 2009. EvaluasiKinerjaSumberDayaManusi a, teori, aplikasi, danpenelitian. Jakarta: Salemba Empat

\section{BIOGRAPHY} Mandala Jember

NurAhmadi, S.Pd, MM was born on Banyuwangi $16^{\text {th }}$ of February 1981. He graduated from SDN 2 BAGOREJO in 1993, SMPN 1 SRONO 1996 and SMAN 1 ROGOJAMPI graduated in 1999. After that, the friendlier teacher studied in one of state universities in Bali. He got the bachelor of history education in 2004. In 2015 he got scolarchip and continue his study in STIE MANDALA JEMBER. He finished it in 2017. He has been a teacher since 2005 and accepted as civil servant in 2006. After that he dedicated his career in SMAN 1 GAMBIRAN until now as vice principalof curriculum. 